\title{
Correction to: Clitoral leiomyoma in a premenopausal woman: a case report
}

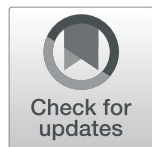

Gianmarco Taraschi ${ }^{{ }^{*}}$, Diego Aguiar ${ }^{2}$, Jean Christophe Tille ${ }^{2}$, Patrick Petignat ${ }^{1}$ and Jasmine Abdulcadir ${ }^{1}$

\section{Correction to: BMC Women's Health (2020) 20:89 https://doi.org/10.1186/s12905-020-00959-x}

Following publication of the original article [1], the authors identified an error in figure order display and figure legends.

The correct figure order and respective legends is shown below:

\section{Author details}

'Department of Obstetrics and Gynaecology, Geneva University Hospitals, 30 Bld de la Cluse, 1211 Geneva, Switzerland. 'Division of Clinical Pathology, Geneva University Hospital, 1 rue Michel-Servet, 1205 Geneva, Switzerland.

Published online: 20 May 2020

\section{Reference}

1. Taraschi G, et al. Clitoral leiomyoma in a premenopausal woman: a case report. BMC Women's Health. 2020;20:89. https://doi.org/10.1186/ s12905-020-00959-x.

The original article can be found online at https://doi.org/10.1186/s12905020-00959-x

*Correspondence: Taraschi@hcuge.ch

'Department of Obstetrics and Gynaecology, Geneva University Hospitals, 30 Bld de la Cluse, 1211 Geneva, Switzerland

Full list of author information is available at the end of the article

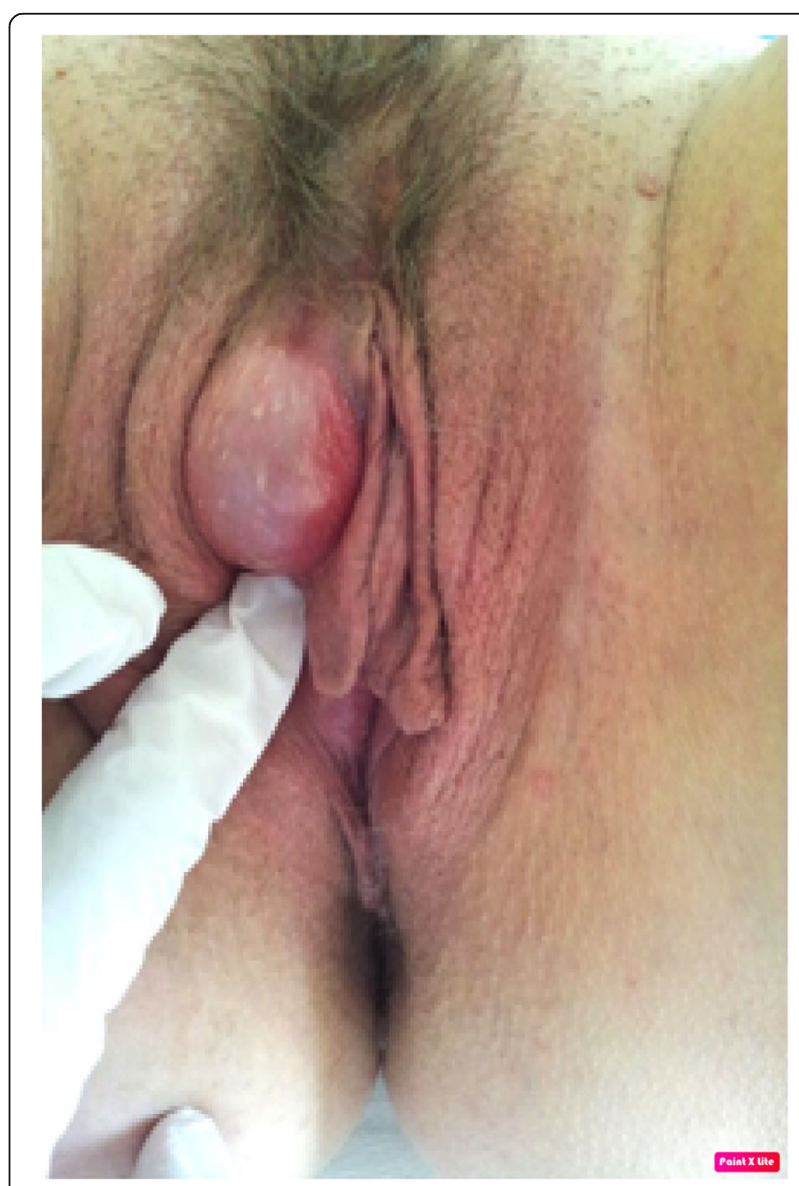

Fig. 1 Physical examination, soft bi-lobated fluid-filled swelling of the right interlabial fossa slightly diverting the clitoris on the opposite side. The pathologic examination showed a Bartholin's gland cyst, which was surprising considering the anatomical localization of this lesion

(c) The Author(s). 2020 Open Access This article is licensed under a Creative Commons Attribution 4.0 International License, which permits use, sharing, adaptation, distribution and reproduction in any medium or format, as long as you give appropriate credit to the original author(s) and the source, provide a link to the Creative Commons licence, and indicate if changes were made. The images or other third party material in this article are included in the article's Creative Commons licence, unless indicated otherwise in a credit line to the material. If material is not included in the article's Creative Commons licence and your intended use is not permitted by statutory regulation or exceeds the permitted use, you will need to obtain permission directly from the copyright holder. To view a copy of this licence, visit http://creativecommons.org/licenses/by/4.0/ The Creative Commons Public Domain Dedication waiver (http://creativecommons.org/publicdomain/zero/1.0/) applies to the data made available in this article, unless otherwise stated in a credit line to the data. 


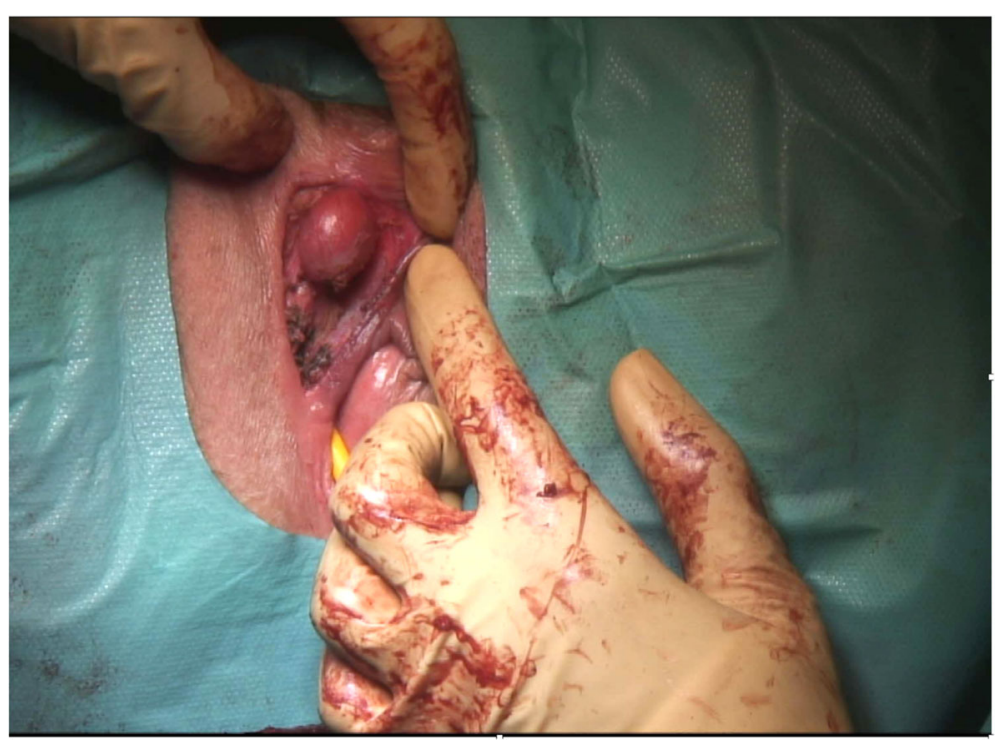

Fig. 2 Intra-operative image of the leiomyoma arising from the right side of clitoris after excision of the first Bartholin's gland cyst

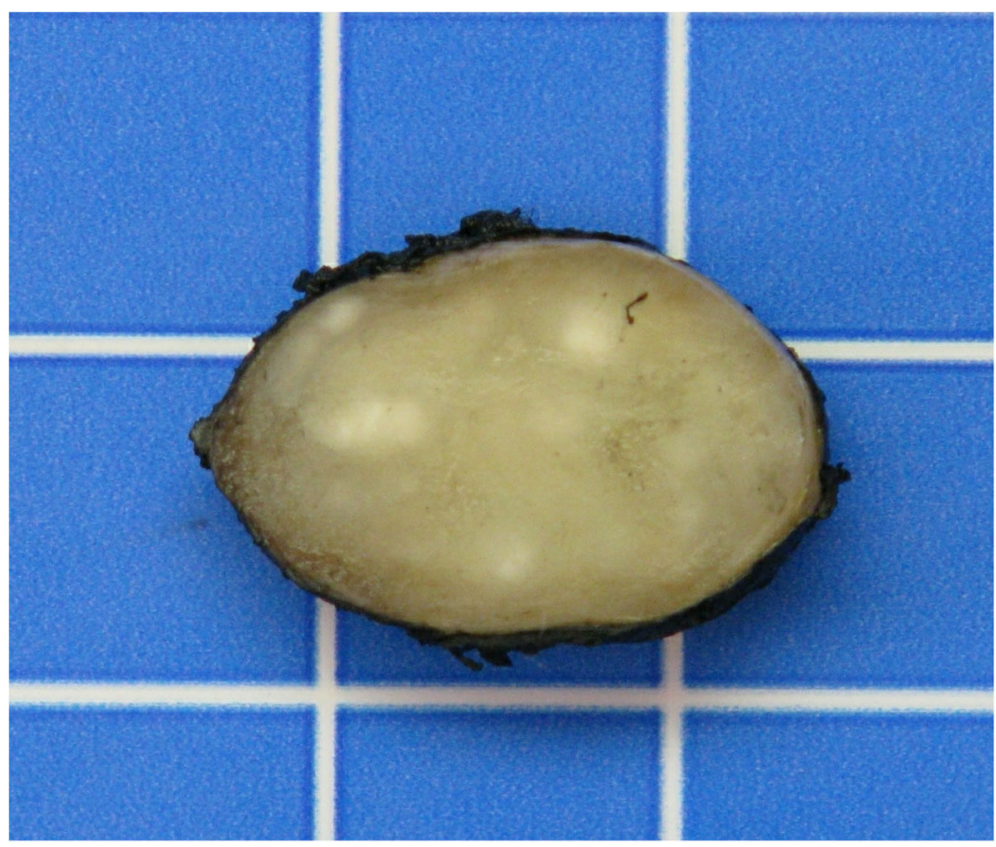

Fig. 3 Macroscopic view of the clitoridal mass. (1 square is $1 \mathrm{~cm}$ ) 


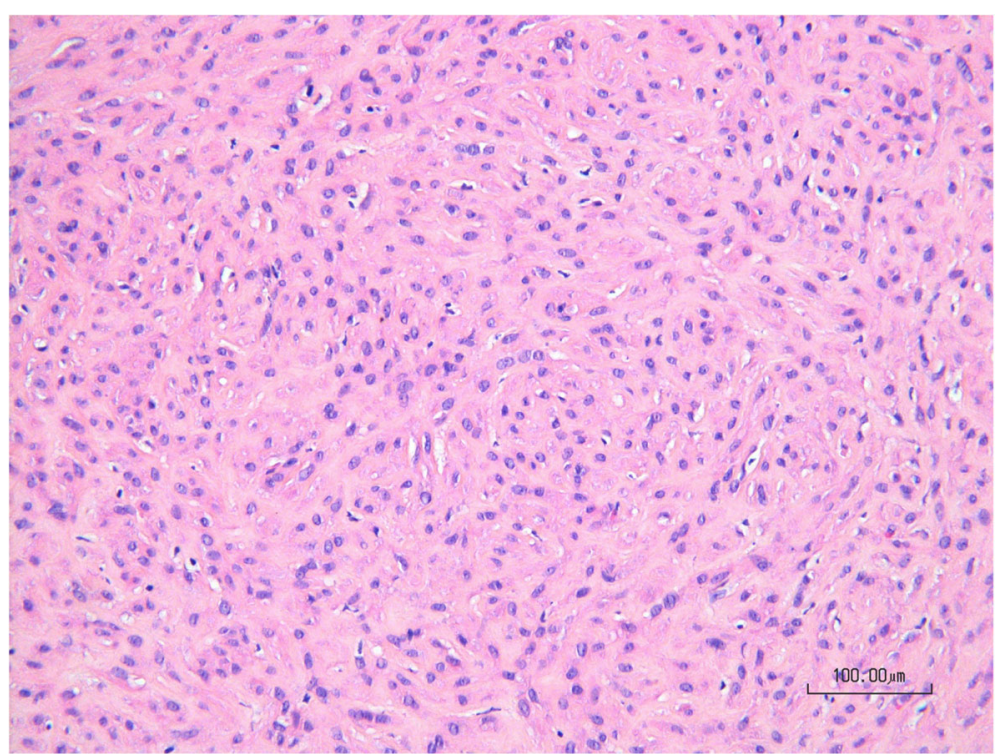

Fig. 4 Microscopic aspect of the clitoridal mass showing intersecting fascicles of spindled cells intermixed with collagen (HE, 200x)

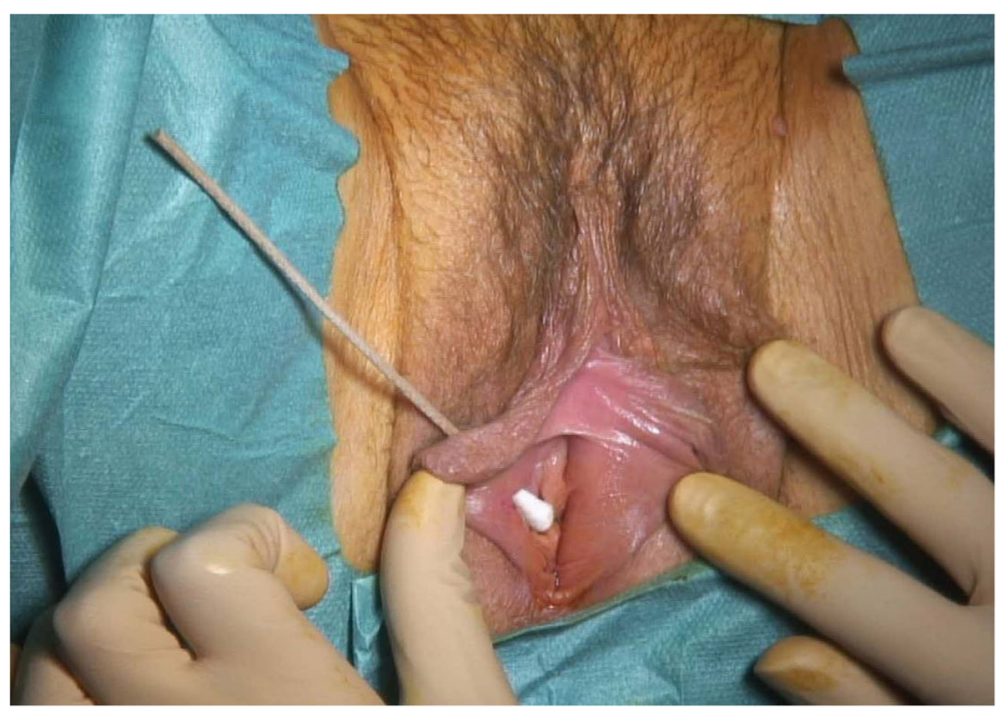

Fig. 5 Intra-operative image of the vulvar defect at 6 months after the first surgery. After first surgery, the patient complained of superficial dyspareunia. At clinical examination, a $7 \mathrm{~mm}$ skin defect was discovered. Initially conservative management was undertaken with unsatisfying evolution. A surgical correction was proposed and accepted by the patient 